\title{
An Overview of Health Control in Croatian Aquaculture
}

\author{
D. Oraić* and S. Zrnčić \\ Croatian Veterinary Institute, Department of Fish Diseases, Savska 143, 10000, \\ Zagreb, Croatia \\ *Correspondence: E-mail: oraic@irb.hr
}

Oraić, D. and Zrnčić, S., 2005. An overview of health control in Croatian aquaculture. Veterinary Research Communications, 29(Suppl. 2), 139-142

\section{ABSTRACT}

\begin{abstract}
Aquaculture is an important segment of Croatian fishing industry with long tradition of carp and rainbow trout farming as well as marine aquaculture represented by shellfish (flat oyster and mussels), sea bass and sea bream cultivation and Atlantic bluefin tuna fattening. The fish and shellfish diseases survey is regulated by "Decree on the measures of animal health protection against infectious and parasite diseases" issued yearly by Ministry of Agriculture. This report derives from systematic clinical, parasitological, pathoanatomical, histopathological, bacteriological and virological monitoring of cultivated fish and shellfish on larger part of production during last several years. Among pathological conditions recognised on our farms, some specific viruses, bacteria and parasites represent frequently established causative nosologic agents. The overview of the main diseases with economic impact to the cultivation will be discussed in this paper.
\end{abstract}

Keywords: diseases, freshwater fish, health control, marine fish, production

\section{INTRODUCTION}

Croatia has a millennium old tradition of shellfish farming and a century old tradition of freshwater fish farming. It was among the first countries which started farming marine fish species, seabass and seabream, and more recently began with Atlantic bluefin tuna fattening. The annual aquaculture production is around 16.000 tons out of which around 6.000 tons belong to freshwater fish, 3.000 tons to marine fish species, 4.000 tons to atlantic bluefin tuna fattening and 1.000 tons to shellfish species (Croatian Chamber of Economy, 2003).

Carp aquaculture is the most important type of freshwater fish cultivation based on polyculture of common carp (Cyprinus carpio), grass carp (Ctenopharingodon idella), silver carp (Hypophtalmycthys molitrix), bighead (Aristichthys nobilis), European catfish (Silurus glanis), pike (Esox lucius) and pike-perch (Stizostedion lucioperca). Salmonid farming is based on the cultivation of rainbow trout (Oncorhynchus mykiss) while same attempts have been made to cultivate some other native species like brown trout (Salmo trutta fario).

The research projects on spawning and cultivation of commercially interesting marine fish species started thirty years ago. From that period cage cultivation of sea bass (Dicentrarchus labrax) and gilthead seabream (Sparus aurata) has reached the production of 3.000 tons per year. The cage fattening Atlantic bluefin tuna (Thunnus thynnus) started quite recently in 1997. European flat oyster (Ostrea edulis) and mussel (Mytilus galloprovincialis) are 
traditionally cultivated in several places along the east side of the Adriatic coast (Dujmušić, 1998).

\section{ORGANIZATION OF HEALTH CONTROL}

As in other animal production activities, diseases are one of the critical points causing important and recurrent losses (Figueras and Novoa, 2004). Keeping in mind that "Prevention is better than Cure" and probably also more cost effective, it is most important to give priority to introducing preventive measures against introduction of pathogens into aquaculture facility environment. The fish and shellfish diseases survey is regulated by "Decree on the measures of animal health protection against infectious and parasite diseases" issued yearly by Ministry of Agriculture and includes diseases listed by OIE, which means control of viral diseases like Viral haemorrhagic septicaemia (VHS), Infectious haematopoietic necrosis (IHN), Spring viraemia of carp (SVC), as well as Infectious pancreatic necrosis (IPN) and Viral encephalopathy and retinopathy (VER) and Marteiliosis and Bonamiosis of flat oyster and Marteiliosis of mussels. Moreover, some fish farms are under continuous health control which contributes to the achievement of the overall epizootiological data collection comprising the information about bacterial, parasitic and fungal diseases.

\section{Main health problems in carp farming}

SVC was first described in 1970s (Fijan et al., 1971) and several outbreaks were noted in 1980s while in the last twenty years there have been no reports of the disease. The most common bacterial problems are caused by Aeromonas salmonicida subsp. nova the causative agent of carp erytrodermatitis, cytophaga-like bacteria (Flavobacterium, Flexibacter) develop bacterial gill disease and Pseudomonas fluorescens of bighead carp as opportunistic bacteria (Petrinec et al., 1985). Parasitic agents are common but they cause serious health problems only occasionally. The most common ectoparasitic infections are caused by ciliates Apiosoma sp., Trichodina sp., Ichtyobodo necatri,x Ichthyophthyrius multifiliis and Chilodonella sp., monogenean Dactylogyrus vastator, digenea Diplostomum spathaceum, and Arthropoda Lernea spp., Ergasilus spp. and Argulus foliaceus (Oraić et al., 2001). Swimbladder inflammation caused by myxosporean Sphaerospora renicola is a serious endoparasitic problem which raises carp fry mortalities up to 60\%. (Zrnčić, 1990). Losses due to massive invasion by Botriocepahus gowkongensis and Caryophyllaeus spp. are sporadic.

\section{Main health problems in trout farming}

The main pathogenic microorganisms isolated were bacteria Yersinia ruckeri (Oraić et al., 2002), cytophaga-like bacteria, Aeromonas salmonicida and Renibacterium salmoninarum. The pathogenic parasite species corresponded to ciliates Ichthyophtirius multifiliis and monogeneas Dactylogyrus spp and Gyrodactylus spp. The most common fungus problems 
affecting cultivated Salmonid fish are those from genus Saprolegnia. Until now there have been no reports of viral diseases.

\section{Main health problems in marine fish farming}

The most frequent problems in marine fish farming are bacterial infections, vibriosis, pseudotuberculosis and superficial bacterial infections. There have been isolated reports of Listonella anguillarum, Photobacterium damsela subsp. piscicida, cytophaga-like bacteria (Flexibacter spp.) and Pseudomonas anguilliseptica in winter disease complex (Oraić et al., 1998). The parasitic species observed in cultured sea bass and sea bream are metazoans Diplectanum spp., Microcotyle spp., Lernathropus spp., Ceratothoa oestroides as well as protozoans Sphaerospora dicentrarchi (Mladineo and Valić, 2002). Myxidium leei is one of the most damaging endoparasites in cultured sharpsnout seabream (Puntazzo puntazzo) (Zrnić et al., 1998). Viral diseases are represented by lymphocistis (Iridoviridae) and epitelocystis due to rickettia in sea bream. In cage fattening of Atlantic bluefin tuna, nematode parasite compatible with Hysterothylaceum sp. and Anisakis spp. were observed (Oraić et al., 2003).

\section{Diseases survey of molluscs in Croatia}

Monitoring plan has been created in cooperation with IFREMER, France. Three epizootiological zones along the coast with several sampling points were determined. Monitoring of two notifiable diseases on European flat oyster hasn't revealed protozoan parasites Bonamia ostreae nor Marteilia refrigens. Protozoan parasite Marteilia maurini was detected in mussels with prevalence of 2-10\%, without mortality reports (Zrnčić et al., 2001).

\section{CONCLUSIONS}

In the last 10 years aquaculture production in Croatia has increased from 5000 tons to over 16000 tons per year out of which marine fish and shellfish present $57 \%$ and freshwater fish $43 \%$. The diseases listed in the "Decree on the measures of animal health protection against infectious and parasite diseases" issued by Croatian Ministry of Agriculture are based on the diseases listed by OIE. The surveillance for viral diseases has been mainly based on the testing procedures given by EU RLFD, Denmark. Considering good natural conditions and relatively small number of aquaculture facilities serious disease outbreaks occur only occasionally.

\section{REFERENCES}

Croatian Chamber of Economy, Association of FISH and fish Processing, 2003. Croatian Aquaculture, 1-24 Dujmušić, 1998. The fishery industry in Croatia. Eastfish Fishery industry, 12, 1-73

Figueras, A. and Novoa, B., 2004. What has been going on in Europe bivalve pathology? Bulletin of the European Association of Fish Pathologists, 24, 16-21 
Fijan, N., Petrinec, Z. and Sulimanović, D., 1971. Isolation of the viral causative agent from the acute form of infectious dropsy of carp. Veterinarski arhiv, 41, 125-138

Mladineo, N. and Valic, D., 2002. The mechanisms of infection of the buccal isopod Ceratothoa oestroides (Risso, 1836), under experimental conditions. Bulletin of the European Association of Fish Pathologists, 22, 304-310

Oraić, D., Zrničić, S. and Soštarić, B., 1998. The Most Prevalent Diseases in Cultivated Sea Bass (Dicentrarchus labrax) and Sea Bream (Sparus aurata) in Fish Farms Along the Croatian Coast. Third International Symposium on Aquatic Animal Health. Baltimore, Maryland, USA

Oraić, D., Zrnčić, S. and Salajster, M., 2001. Preventiva, kontrola bolesti i ocjena higijenske kakvoće riba i školjaka. 1-68. Hrvatski veterinarski institut, Zagreb

Oraić, D., Zrnčić, S., Šoštarić, B., Bažulić, D. and Lipej, Z., 2002. Occurrence of enteric red mouth disease in rainbow trout (Oncorhynchus mykiss) on farms in Croatia. Acta Veterinaria Hungarica, 50, 283-291

Oraić, D., Zrnčić, S. and Šoštarić, B., 2003. Lesions of possible parasitic etiology in Atlantic bluefin tuna (Thunnus thynnus). EAFP 11th International Conference on "Diseases of Fish and Shellfish". Book of Abstracts, P-105

Petrinec, Z., Naglić, T., Matašin, Ž. and Fijan, N., 1985. Pseudomonas fluorescens septicaemia in bighead carp (Aristichythis nobilis, Rich.) following handling. Veterinarski Arhiv, 55, 277-284

Zrnčić, S., 1990. Putevi širenja upale ribljeg mjehura u šarana (Cyprinus carpio, L.). Magistarska rasprava. (Zagreb)

Zrnčić, S., Oraić, D., Šoštarić, B. and Filić, I., 1998. First Occurrence of Myxidium leei in Cultivated Charp Snouted Sparus (Puntazzo puntazzo) in Croatia. Third International Symposium on Aquatic Animal Health. Baltimore, Maryland, USA.

Zrnčić, S., Le Roux, F., Oraić, D., Šoštarić, B. and Berthe, F.C.J., 2001. First record of Marteilia sp. in mussels Mytilus galloprovincialis in Croatia. Diseases of Aquatic Organisms on the Measures of Animal Health Protection Against Infectious and Parasite Diseases, 44, 143-148 